\title{
O NIEWSTYDACH, NIEWSTYDNIKACH I NIEWSTYDLIWCACH W POLSZCZYŹNIE I INNYCH JĘZYKACH SŁOWIAŃSKICH
}

\author{
Irena Jaros \\ Uniwersytet Łódzki \\ ORCID: 0000-0001-6397-5890
}

\begin{abstract}
Streszczenie: Na podstawie polskich oraz innosłowiańskich źródeł historycznych i gwarowych autorka omawia genezę oraz zasięg występowania leksemów niewstyd, niewstydnik, niewstydnica i niewstydliwiec o wspólnym znaczeniu 'człowiek pozbawiony wstydu, nikczemny'. Są to archaizmy, które stosunkowo krótko funkcjonowały w polszczyźnie ogólnej (XVII-XVIII w.). Zostały z niej wyparte przez szerzące się od połowy XVII wie$\mathrm{ku}$ derywaty bezwstydnik i bezwstydnica. Aktualne występowanie podobnych formacji z prefiksem nie- w języku czeskim oraz ich historyczne poświadczenia ze wszystkich języków wschodniosłowiańskich dowodzą, że były to w przeszłości formy funkcjonujące na dużym terenie Słowiańszczyzny. Na polskim obszarze językowym swoją żywotność dłużej zachowały tylko w gwarach ludowych. Ich obecność, stosunkowo niewielka w Polsce centralnej i północnej, skupia się głównie na południu (Śląsk, Małopolska) i południowym wschodzie.
\end{abstract}

Słowa klucze: historia języka polskiego, dialektologia, leksyka, słowotwórstwo

Zarówno w języku polskim, jak i w innych językach słowiańskich ${ }^{1}$ funkcjonuje prefiks nie-, którego podstawową funkcją jest wnoszenie do derywatu znaczenia zaprzeczenia, braku lub przeciwstawności tego, co wyraża wyraz motywujący. Ten podstawowy w funkcji negacyjnej formant ${ }^{2}$ tworzy w polszczyźnie m.in. szereg formacji odprzymiotnikowych o znaczeniu przeciwstawnym wobec podstawy, np. niemily od mity, niedrogi od drogi oraz zaprzeczenia imiesłowów biernych typu: niewyczerpany od wyczerpa$n y$. Jest także częścią derywatów odrzeczownikowych ${ }^{3}$, przede wszystkim informujących o braku tego, co oznacza rzeczownik podstawowy, np. nie-

1 Por. np. wschodniosłowiańskie нe-, oraz czes., słow. ne-

2 Zob. R. Grzegorczykowa, R. Laskowski, H. Wróbel, Gramatyka wspótczesnego języka polskiego. Morfologia, Warszawa 1998, s. 502.

3 Zob. A. Pstyga, Stowotwórcza kategoria negacji. Prefiksalne negatywa rzeczownikowe we współczesnym języku polskim i rosyjskim, Gdańsk 2010, s. 107, tab. 1. 
szczęście od szczęście, niełaska od taska, nieuwaga od uwaga, niesława od sława. Wśród polskich derywatów z prefiksem nie- odnajdujemy także wiele formacji nazywających zaprzeczone nazwy czynności, np. niepisanie, nieklasyfikowanie, nazwy nosicieli cech, np. niemowa, nieprzyjaciel, oraz nazwy wykonawców czynności, np. nierób, nieuk. Tworzą one dość bogaty zbiór rzeczowników, w którym wyjątkowe miejsce zajmują nazwy ludzi charakteryzujących się postępowaniem niezgodnym z ustalonymi normami i zasadami społecznymi, niemających czy nieznających uczucia wstydu. Są to notowane w polskich gwarach oraz w polszczyźnie historycznej derywaty posiadające w swojej strukturze prefiks nie-: niewstyd (r. męski), niewstyda (r. męski i żeński), niewstydnik i niewstydnica oraz jednostkowo niewstydliwiec. Nie są one rejestrowane przez współczesne słowniki języka polskiego, np. Uniwersalny stownik języka polskiego ${ }^{4}$ czy Praktyczny stownik wspótczesnej polszczyzny ${ }^{5}$, zastąpiły je bowiem szerzące się w polszczyźnie od poł XVII wieku ${ }^{6}$ formacje: bezwstydnik i bezwstydnica, pełniące we współczesnej polszczyźnie tę samą funkcję znaczeniową ${ }^{7}$ Należy uznać więc je za formacje archaiczne, których dłuższy żywot w polszczyźnie został ograniczony jedynie do gwar ludowych.

Celem artykułu jest zwrócenie uwagi na te interesujące, ale nieużywane w dzisiejszej polszczyźnie ogólnej formacje, ich genezę oraz geografię, uwzględniającą szersze - zachodnio-i wschodniosłowiańskie tło. Dane językowe egzemplifikujące te zagadnienia pochodzą z dzieł drukowanych, tzn. $\mathrm{z}$ historycznych słowników języka polskiego ${ }^{8}$, ze słowników i monografii gwarowych ${ }^{9}$, oraz

\footnotetext{
$4 \quad$ S. Dubisz (red.), Uniwersalny stownik języka polskiego, t. 1-4, Warszawa 2003.

5 H. Zgółkowa (red.), Praktyczny stownik wspótczesnej polszczyzny, t. 1-50, Poznań 1995
} 2005.

6 Elektroniczny slownik języka polskiego XVII i XVIII wieku, sv. bezwstydnik, online: https:// sxvii.pl/; zob. S. Dubisz, op.cit.; H. Zgółkowa, op.cit.

7 Hasło: Niewstyd występuje w Słowniku języka polskiego pod red. W. Doroszewskiego, dokument elektroniczny, Warszawa 1997 z kwalifikatorem daw. w znaczeniu „brak wstydu, bezwstyd; czyn, postępek bezwstydny”. W tym samym znaczeniu pojawił się wyraz niewstyd w kilku cytatach występujących w Narodowym Korpusie Języka Polskiego, online: http://www. nkjp.uni.lodz.pl.

$8 \quad$ S.B. Linde, Stownik języka polskiego, wyd. 2, t. 3, Warszawa 1857, sv. wstyd; M.R. Mayenowa, F. Pepłowski (red.), Słownik polszczyzny XVI w., t. 18, Warszawa 1988; J. Karłowicz, A. Kryński, W. Niedźwiedzki (red.), Stownik języka polskiego, t. 3, Wrocław-Warszawa 1904; A. Zdanowicz i in. (red.), Stownik języka polskiego, t. 1-2, Wilno 1861, online: http://eswil. ijp-pan.krakow.pl.

9 J. Karłowicz, Stownik gwar polskich, t. 3, Warszawa 1903; J. Kąś, Ilustrowany leksykon gwary i kultury podhalańskiej, t. 6, Nowy Sącz 2018; J. Chludzińska-Świątecka, Budowa stowotwórcza rzeczowników w gwarach Warmii i Mazur, „Prace Filologiczne” 22, 1972, s. 159-289; H. Górnowicz, Dialekt malborski, t. 2, Gdańsk 1973-1974; J.K. Nowak, Stownik gwary górali żywieckich, Żywiec-Grojec-Warszawa 2012; W. Steffen, Stownik warmiński, Wrocław 1984; 
niedrukowanych słowników ${ }^{10} \mathrm{i}$ źródeł publikowanych w Internecie, tzn. z kartoteki Stownika gwar polskich PAN ${ }^{11}$, kartoteki Słownika języka polskiego XVII $i$ pot XVIII w. ${ }^{12}$ oraz elektronicznego korpusu tekstów barokowych KORBA ${ }^{13}$. Przytaczane formy gwarowe pochodzą z dość rozległego okresu - od końca XIX wieku (np. ze Słownika gwar polskich J. Karłowicza ${ }^{14}$ ) do drugiej połowy wieku XX. Trudno aktualnie ocenić, czy omawiane leksemy należą współcześnie do czynnego słownictwa użytkowników gwar, czy są jedynie przywoływane z pamięci, czy też są w ogóle zapomniane. Ze względu na ich historyczną proweniencję uznaję je za należące do dawnej, archaicznej warstwy leksyki gwarowej, bez formułowania wniosków na temat ich żywotności w gwarach polskich

\section{NIEWSTYD, NIEWSTYDA, NIEWSTYDAK}

Forma niewstyd posiadała $\mathrm{w}$ średniopolszczyźnie kilka znaczeń, m.in 'bezczelność, zuchwalstwo, brak wstydu', 'niemoralne postępowanie, rozwiązłość seksualna', 'hańba' oraz funkcjonowała jako określenie 'człowieka bezczelnego, niemającego wstydu' ${ }^{15}$. W tym ostatnim znaczeniu pojawia się jedynie w dziełach z XVII i XVIII wieku, np.: Biada złoczyńcom, biada okrutnikom, biada niewstydom, biada wszetecznikom, 1670 (KORBA), wszelkiego nierzadu pilnujesz, pijaku, kostyro, niecnoto, niewstydzie i obmierzły kiernozie, 1715 (KORBA). Formy tej nie notuje w ogóle Stownik staropolski ${ }^{16}$, zaś Stownik polszczyzny XVI wieku rejestruje ją, ale bez znaczenia osobowego ${ }^{17}$. Przedstawiona w słowniku tym semantyka wyrazu niewstyd odnosi się jedynie do zachowań zuchwałych, bezwstydnych oraz czynów nieobyczajnych, nierządu. Późniejsze źródła historyczne, zawierające słownictwo funkcjonujące $\mathrm{w}$ języku polskim po XVIII wieku, albo wskazują na gwarową proweniencję ${ }^{18}$

B. Sychta, Stownik gwar kaszubskich na tle kultury ludowej, t. 7, Wrocław 1976; M. Szymczak, Stownik gwary Domaniewka w powiecie tęczyckim, cz. 4, Wrocław-Warszawa-Kraków 1965.

10 Elektroniczny słownik języka polskiego XVII i XVIII wieku.

11 Kartoteka Stownika gwar polskich PAN - dalej w tekście skrót KSGP PAN, online https:// rcin.org.pl/dlibra/publication/37740/edition/21859/content.

12 Kartoteka Stownika XVII wieku i 1. połowy XVIII wieku - dalej w tekście KSJPXVII/XVIII, online: https://www.rcin.org.pl/dlibra/publication/21804/edition/7639.

13 Elektroniczny Korpus Tekstów Polskich z XVII i XVIII w. (do 1772 r.) - dalej KORBA, online: https://korba.edu.pl/query_corpus/.

14 J. Karłowicz, op. cit.

15 Zob. S.B. Linde, op. cit.; M.R. Mayenowa, F. Pepłowski, op. cit.; Elektroniczny słownik języka polskiego...

16 S. Urbańczyk (red.), Stownik staropolski, t. 1-11, Kraków 1953-2002.

17 Zob. M.R. Mayenowa, F. Pepłowski, op. cit., s. 276-277, sv. niewstyd.

18 J. Karłowicz, A. Kryński, W. Niedźwiedzki, op. cit. 
omawianego leksemu, albo rejestrują jego rzadkie ${ }^{19}$ lub dawne ${ }^{20}$ znaczenie: 'czyn, postępek bezwstydny'. Słownik języka polskiego, tzw. wileński, zawiera wprawdzie hasło: niewstyd, ale z odsyłaczem do innego, zapewne bardziej rozpowszechnionego w języku polskim w XIX wieku wyrazu: bezwstyd ${ }^{21}$ Obecność tego leksemu w polszczyźnie w szerszym zakresie potwierdzają źródła gwarowe, w których notowany jest zarówno w znaczeniu osobowym, np. w Słowniku gwar polskich Jana Karłowicza: Niewstydzie! = połajanka $\mathrm{z}$ Domaniewic, w pow. łowickim ${ }^{22}$ oraz Ty niewstydzie jeden $\mathrm{z}$ sieradzkiego ${ }^{23}$, jak i w znaczeniu abstrakcyjnym: 'bezwstyd, brak wstydu', np. w gwarach łęczyckich, w Domaniewku" ${ }^{24}$ niewstyd cie takie rzecy robić; to niewstyd ci tak dtugo się wyligac ${ }^{25}$ oraz na Warmii: Co za niewstyd chodzić i żebrać tlo po to żeby mńyć źańci pśeniandzy ${ }^{26}$ i na Podhalu: Tako dziywka ino niewstyd robi ojcowi ${ }^{27}$.

W polskich gwarach forma niewstyd w znaczeniu 'człowiek bezwstydny' stała się podstawą do utworzenia jej wariantów słowotwórczych: paradygmatycznego derywatu niewstyda oraz sufiksalnego niewstydak. Gwarowe określenie niewstyda mogło odnosić się do obu płci, zarówno do kobiet (ta niewstyda), jak i do mężczyzn (ten niewstyda), np. masc. i fem.: Zaryte, pow. nowotarski ${ }^{28}$, Harbutowice, pow. cieszyński: Jak ci ni ma gańba, ty niewstydo; fem.: Myślenice-Zarabie, pow. myślenicki: Wstaj biedo niewstyda, pudziemy do ludzi (KSGP PAN), gwary podhalańskie ${ }^{29}$ : Niewstyda ta Hanka! Żeby tak prziś do kościoła ubrano!; Jakoz to godos ty niewstydo, dziywcęciu sie nie nolezy tak godać uogrubnie, okolice Żywca ${ }^{30}$; masc.: Sromowce Wyżne, pow. nowotarski, Czchów nad Dunajcem, pow. brzeski, na południe od Chrzanowa, Ślemień, pow. żywiecki (KSGP PAN); niewstyda albo niestyda (masc.) Podhale ${ }^{31}$. Derywat sufiksalny: niewstydok 'bezwstydnik, człowiek pozbawiony

\footnotetext{
Ibidem.

W. Doroszewski, op. cit.

A. Zdanowicz i in., op. cit.

J. Karłowicz, op. cit.

Forma znana autorce ze słyszenia, przywołana przez informatora z pamięci.

Ponieważ przytoczone przykłady i cytaty pochodzą z różnych źródeł, w których używano niejednolitego sposobu zapisu (ortograficzny $\mathrm{i} /$ lub fonetyczny), zrezygnowano w zasadzie ze stosowania znaków fonetycznych i ograniczono do minimum oddawanie w piśmie zjawisk fonetycznych występujących w przykładach.

25 M. Szymczak, op. cit

26 W. Steffen, op. cit.

27 J. Kąś, op. cit.

28 Podane w starszych źródłach nazwy powiatów, odnoszące się do konkretnych wsi, zostały zaktualizowane, wg podziału administracyjnego Polski z roku 1999.

29 Ibidem.

30 J.K. Nowak, op. cit.

31 J. Karłowicz, op. cit.
} 
honoru' został zanotowany w okolicach Żywca ${ }^{32}$, np.: Niewstydok - mo potargane portki na rzici. Niewstydoki chtodzom po nagu.

Geneza derywatu niewstydnik pozostaje w związku z jego znaczeniem słowotwórczym, tzn. 'mężczyzna niewstydny', wskazującym na bezpośrednią podstawę przymiotnikową ${ }^{33}$. Forma żeńska: niewstydnica powstała albo jako paradygmatyczny derywat modyfikacyjny od formy męskiej, albo bezpośrednio od przymiotnika 'niewstydna dziewczyna, kobieta'. O historycznym wymiarze procesu ich powstania może świadczyć brak wskazanego przymiotnika (nie)wstydny w ogólnopolskich źródłach leksykograficznych pochodzących z XX wieku ${ }^{34}$. Notują go rzadko źródła historyczne od XVII wieku, np. wstydny uczynek ${ }^{35}$, niewstydny (KSJPXVII/XVIII). Stownik języka polskiego, tzw. warszawski ${ }^{36}$, zamieszcza go $\mathrm{z}$ kwalifikatorem rzadko używany i potwierdza cytatem z XVIII wieku: Nimfy oczu niewstydnych i lica ${ }^{37}$. Pośrednio o jego dawnym funkcjonowaniu w polszczyźnie może świadczyć przysłówek niewstydnie i rzeczownik niewstydność notowane przez słowniki: tzw. warszawski i wileński ${ }^{38}$. Powstałe od przymiotnika niewstydny rzeczowniki niewstydnik i niewstydnica występują w źródłach XVII- i XVIII-wiecznych, por.: Po weselu przypomina się niewstydnica stowa przyobiecanego u Galeziusza XVII/XVIII wiek, Chociak się za tym y tu Jozef chroni/Następuiacey iak może napaści/ Przeni go owa niewstydnica goni 1745, Bez wstydu niewstydnik, niewstydnica 1746 (KSJPXVII/XVIII). W XIX-wiecznych słownikach opatrzone są one kwalifikatorami wskazującymi na ich dawnośćc ${ }^{9}$.

Dłużej przymiotnik niewstydny albo niestydny zapisywano $\mathrm{w}$ gwarach na terenie całej Polski w znaczeniu 'pozbawiony wstydu, bezwstydny; nie mający skrupułów moralnych', np. w Wielkopolsce, w pow. kaliskim: niewstydny chłopok, dokuczo i dokuczo tej matce, Złotniki; w północnej Małopolsce, w pow. wieluńskim: cielec niewstydny bez kosuli chodzi Przedmość i w pow. starachowickim: niewstydny taki Dąbrowa Poduchowna; w Krakowskiem (KSGP PAN), na Podhalư ${ }^{40}$ : Ty brzidoku niewstydny; na Śląsku, w pow. żywie-

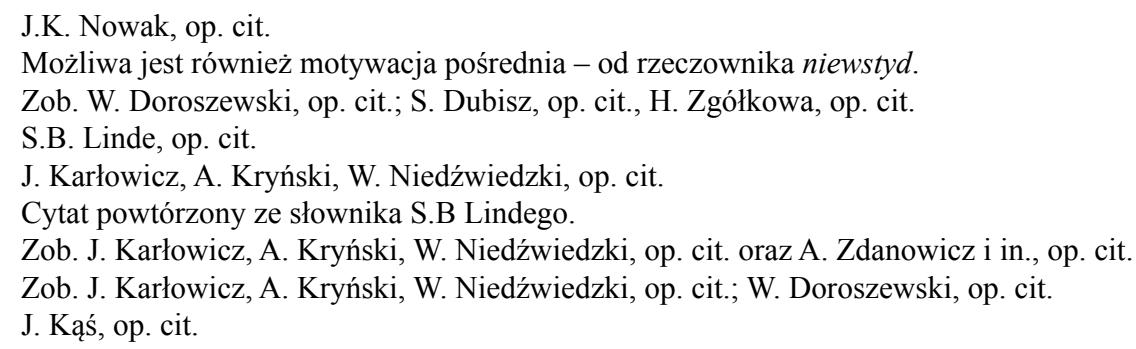


ckim: niestydny Ślemień i w pow. cieszyńskim: niewstydny narod! Zarzecze (KSGP PAN); na Warmii ${ }^{41}$ i w gwarach malborskich ${ }^{42}$ : Co za niewstydna Maryszia, z wsziystkymi szie łajdacziy, oraz na Mazowszu, w pow. ostrołęckim: niewstydna baba Janki Młode, w pow. białobrzeskim: Ty śwynio niewstydno! Szczyty (KSGP PAN) i na Kaszubach ${ }^{43}$ : Co ten niewstëdny strech sobie mësli.

Utworzone od niego derywaty niewstydnik i niewstydnica zostały zarejestrowane przede wszystkim:

- w Małopolsce, np. w Nienadówce, pow. rzeszowski, Bronowicach, pow. krakowski, w Dąbrowie Poduchownej, pow. starachowicki: uo ty niewstydniku jeden! (KSGP PAN),

- na Śląsku, np. w pow. wodzisławskim: Ty niestydniku, jako sie tak umisz seblyc przed ludziami Rogów, w pow. cieszyńskim: Nale ty niewstydniku jedyn! Kozakowice, na Śląsku Opolskim, w pow. strzeleckim: A kebyś tak prziszot [pijany] (...) to ta żonka roztomiyło po pysku ci data (...) i jeszcze niystydnikym abo i gorzi ku tymu miónuje Zawady, w pow. prudnickim: tyj niestydniku! Dzierżysławice (KSGP PAN),

- na Warmii i Mazurach ${ }^{44}$,

- na Mazowszu w Adamowie, pow. mławski, w Jankach Młodych, pow. ostrołęcki, w Olszance, pow. suwalski: niewstydnico jedna (KSGP PAN),

- na Kaszubach ${ }^{45}$ : Że sa też Boga nie bojisz niëwstedniku!; Ta niewstëdnica miała bë sa lëdzy bojec, kiej ona sa Boga nie boji.

Innym, synonimicznym $\mathrm{w}$ stosunku do niewstydnika, derywatem jest nieobecny w źródłach gwarowych, jednostkowo zarejestrowany w 1579 r. w Żywotach świętych Piotra Skargi ${ }^{46}$, a przez słownik warszawski ${ }^{47}$ uznany za wyraz przestarzały, leksem niewstydliwiec "człowiek nie mający wstydu, bezwstydnik' powstały od zaprzeczonego przymiotnika niewstydliwy.

\section{NIEWSTYD, NIEWSTYDA, NIEWSTYDNIK, NIEWSTYDNICA W INNYCH JEZYKACH SŁOWIAŃSKICH}

Występujące w polszczyźnie dawnych wieków oraz w gwarach omawiane formacje niewstyd, niewstyda, niewstydnik, niewstydnica znajdują swoje morfologiczne odpowiedniki w innych, zwłaszcza sąsiadujących z polszczyzną językach słowiańskich. Do dzisiaj derywaty oznaczające ludzi bezwstydnych,

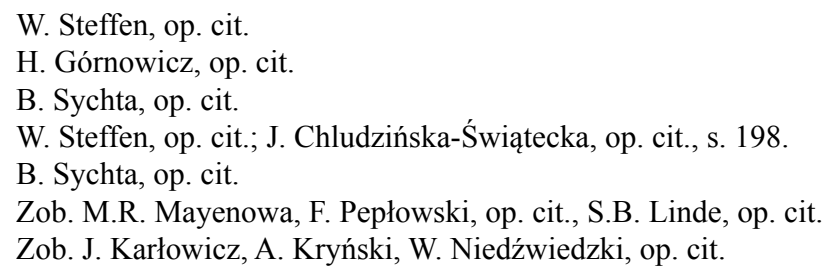


zbudowane analogicznie do omawianych polskich formacji słowotwórczych, funkcjonują w języku czeskim, por. nestoudnik 'bezwstydnik', nestoudnice 'bezwstydnica' ${ }^{48}$. Próżno jednak szukać ich w innych współczesnych ogólnych wariantach języków słowiańskich, w których albo ustaliły się podobnie jak w polszczyźnie derywaty z prefiksalnym bez- i rdzennym -styd-, -studpor. ros. бесстылный 'bezwstydny', бесстыдник, бесстылнииа ${ }^{49}$, albo z pochodzącym od psł. wyrazu srom 'wstyd' ${ }^{50}$ wschodniosłowiańskim rdzeniem -sorom- i południowosłowiańskim -sram-, por. ukr. bezsoromnyj, bezsoromnyk $k^{51}$, bułg. безсра̀мник 'bezwstydnik, nikczemnik', безсра̀мница 'bezwstydnica' ${ }^{52}$. Pewne ślady dawnego funkcjonowania formacji z prefiksalnym ne- (nie-) na terenie wschodniej Słowiańszczyzny odnajdujemy w słownikach historycznych i gwarowych rejestrujących słownictwo z tego obszaru. Stownik języka rosyjskiego XI-XVII wiek $u^{53}$ notuje występowanie w języku staroruskim formy невстылдливый w znaczeniu 'człowiek bezwstydny', zaś Historyczny słownik języka białoruskiego ${ }^{54}$ potwierdza funkcjonowanie w dawnym języku białoruskim formacji невстылдивець 'bezwstydnik' і невстыль 'bezwstydne uczynki, bezwstydność'. W gwarach białoruskich znany jest przymiotnik няўстыдны, zanotowany w miejscowości Łojów na Homelszczyźnie ${ }^{55}$ oraz rzeczownik няўстьлнік, zarejestrowany w północno-zachodniej części gwar białoruskich ${ }^{56}$. Przykłady poświadczające występowanie form z prefiksem ne-, nр. невстѝда, неўстида 'bezwstydnik, bezwstydnica' ${ }^{57}$, нивстѝдник 'bezwstydnik' 58 , odnajdujemy także w ukraińskich gwarach bojkowskich i huculskich. Trudno jednoznacznie określić, czy występowanie omawianych formacji w językach wschodniosłowiańskich oraz $\mathrm{w}$ języku polskim i czeskim wynikało ze wspólnego dziedzictwa prasłowiańskiego

48 J. Siatkowski, Stownik czesko-polski, Warszawa 1991.

49 J. Wawrzyńczyk (red.), Wielki stownik polsko-rosyjski, Warszawa 2009, por. бесcтудный 'bezwstydny', бесстуднинъ, бесстуднииа, [w:] В. Даль, Толковый словарь живаго великорускаго языка, т. 1, Москва 1880.

${ }_{50}$ K. Długosz-Kurczabowa, Wielki stownik etymologiczno-historyczny języka polskiego, Warszawa 2018, sv. wstyd.

51 О. Таланов, Польсько-украӥнський украӥнськио-польський словник, Київ 2016.

52 J. Satoła-Staśkowiak, V. Koseska-Toszewa, przy współpr. L. Dimitrovej, Współczesny stownik bułgarsko-polski, z. 1, Warszawa 2014.

53 Д.Н. Шмелев (ред.), Словарь русского языка XI-XVII вв., вып. 11, Москва 1986.

54 А.М. Булыка (рэд.), Гістарычны слоўнік беларускай мовы, вып. 20, Мінск 1986.

55 Т.С. Янкова, Дыяллектны слоўнік Лоеўшчыны, Мінск 1982, с. 222, online: https://knihi. com/Tamara_Jankova/Dyjalektny_slounik_Lojeuscyny.html\#223, dostęp 14.08.2020.

56 Ю.Ф. Мацкевіч (рэд.), Слоўнік беларускіх гаворак паўночна-заходняй Беларусі $і$ яе пагранічча, т. 3, Мінск 1982, с. 249.

57 М.Й. Онишкевич, Словник бойківсьих говірок, Київ 1984.

58 Ю. Піпаш, Б. Галас, Матеріали до словника гуцульських говірок. Косівська Поляна i Росішка Рахівського району Закарпатської області, Ужгород 2005. 
i podobnych tendencji rozwojowych w zakresie zasobu leksykalnego, czy też miało związek z procesami wzajemnego przenikania słownictwa z powodu wielowiekowych kontaktów językowych tych etnolektów.

\section{WNIOSKI}

Omawiane leksemy niewstyd, niewstydnik, niewstydnica i niewstydliwiec o wspólnym znaczeniu 'człowiek pozbawiony wstydu, nikczemny' to niewątpliwie archaizmy, które stosunkowo krótko były obecne w polszczyźnie ogólnej (XVII-XVIII w.). Ich aktualne występowanie w języku czeskim oraz historyczne poświadczenia ze wszystkich języków wschodniosłowiańskich dowodzą, że były to w przeszłości formy funkcjonujące na dużym terenie Słowiańszczyzny. Na polskim obszarze językowym swoją żywotność dłużej zachowały tylko w gwarach ludowych, które jako odmiany języka etnicznego przechowują słownictwo w dużej mierze ustalone w poprzednich wiekach. Odziedziczony z dawnej polszczyzny zbiór wariantów słowotwórczych (oprócz wyrazu niewstydliwiec) został w gwarach uzupełniony o dwa określenia należące do tej same rodziny wyrazów - niewstyda i niewstydak. Tak skompletowany zasób synonimów był wykorzystywany w konkretnym celu - napiętnowania ludzi, członków tej samej społeczności, postępujących niezgodnie z przyjętymi zasadami społecznymi. Określenia te niosły ze sobą duży ładunek negatywnych emocji, miały niewątpliwie znaczenie pejoratywne, źle oceniające nazywane nimi osoby, co wyraźnie akcentował morfem nie. Funkcjonowanie w tym samym czasie kilku formacji słowotwórczych wyrażających identyczne lub podobne treści, zarówno tych z prefiksem nie-, jak i nowszych z bez-, świadczy o ich rywalizacji, wynikającej przede wszystkim z braku specjalizacji semantycznej formantów. Powodowało to powstanie redundancji leksykalnej, pewnej nadmiarowości, która w dłuższej perspektywie rozwoju języka dążącego do precyzji semantycznej nie mogła się obronić. Pewne wnioski na temat przyczyn krótkiego żywota omawianych leksemów w polszczyźnie można sformułować na podstawie analizy ich terenowej repartycji. Ich obecność na polskim obszarze językowym, stosunkowo niewielka w Polsce centralnej i północnej, skupiająca się głównie na południu (Śląsk, Małopolska) i południowym wschodzie, świadczy o wycofywaniu się analizowanych derywatów z gwar prawdopodobnie pod naporem szerzących się od poł XVII wieku w polszczyźnie ogólnej formacji bezwstydnik, bezwstydnica, tworzonych od wyrażenia bez wstydu. Utrzymywanie się na południu Polski formacji z prefiksalnym nie- mogło być wspierane przez sąsiadujący z nimi język czeski oraz od wschodu - przez gwary ukraińskie. 


\section{BIBLIOGRAFIA}

Ânkova T.S., 1982. Dyâlektny sloǔnik Loeǔščyny. Mìnsk: „Navuka ì tèhnìka”. W: https://knihi.com/Tamara_Jankova/Dyjalektny_slounik_Lojeuscyny.html\#2 [Dostęp: 14.08.2020]. [Янкова Т.С., 1982. Дьялектны слоўнік Лоеўшчыны. Мінск: „Навука і тэхніка”]. W: https://knihi.com/Tamara_Jankova/Dyjalektny_slounik_Lojeuscyny.html\#2 [Dostęp: 14.08.2020].

Bulyka A.M. Rèd. 1986. Gistaryčny sloǔnik belaruskaj movy, vyp. 20, Mìnsk: „Navuka ì tèhnika”. [Булыка А.М. Рэд. 1986. Гістарычны слоўнік беларускай мовы. Вып. 20, Мінск: „Навука і тэхніка”].

Chludzińska-Świątecka Jadwiga. 1972. Budowa słowotwórcza rzeczowników w gwarach Warmii i Mazur. „Prace Filologiczne”. R. 22: 159-289.

Dal' Vladimir. 1880. Tolkovyj slovar' živago velikoruskogo âzyka.T. 1. Moskva: Izdanie knigoprodavca-tipografa M.O. Vol'fa. [Даль Владимир. 1880. Толковый словарь живаго великоруского языка t. 1. Москва: Изданіе книгопродавца -типографа М.О. Вольфа].

Długosz-Kurczabowa Krystyna. 2018. Wielki słownik etymologiczno-historyczny języka polskiego. Warszawa: Wydawnictwo Naukowe PWN

Doroszewski Witold. Red. 1997 (1957-1969). Stownik języka polskiegot. 1-10. Przedruk elektroniczny. Warszawa: Wydawnictwo Naukowe PAN.

Dubisz Stanisław. Red. 2003. Uniwersalny słownik języka polskiego t. 1-4. Warszawa: Wydawnictwo Naukowe PWN.

Elektroniczny stownik języka polskiego XVII i XVIII wieku. Online: https://sxvii.pl/ [Dostęp 25.02.2020].

Górnowicz Hubert. 1973-1974. Dialekt malborski t. 1-2. Gdańsk: Gdańskie Towarzystwo Naukowe.

Grzegorczykowa Renata, Laskowski Roman, Wróbel Henryk. 1998. Gramatyka wspótczesnego języka polskiego. Morfologia. Warszawa: Wydawnictwo Naukowe PWN.

Karłowicz Jan, Kryński Adam Antoni, Niedźwiedzki Władysław. 1900-1927. Słownik języka polskiego t. 1-8. Warszawa: [brak wydawcy].

Karłowicz Jan. 1900-1911. Stownik gwar polskich t. 1-6. Kraków: Akademia Umiejętności.

Kąś Józef. 2018. Ilustrowany leksykon gwary i kultury podhalańskiej t. 6. Nowy Sącz: Małopolskie Centrum Kultury Sokół.

KORBA - Elektroniczny Korpus Tekstów Polskich z XVII i XVIII w. (do 1772 r.). Online: https://korba.edu.pl/query_corpus/ [Dostęp 16.02.2020].

KSGP PAN - kartoteka Stownika gwar polskich PAN. Online https://rcin.org.pl/dlibra/ publication/37740/edition/21859/content [Dostęp 16.02.2020].

KSJPXVII/XVIII - kartoteka Stownika języka polskiego XVII wieku i 1. połowy XVIII wieku. Online: https://www.rcin.org.pl/dlibra/publication/21804/edition/7639 [Dostęp 16.02.2020].

Linde Samuel Bogumił. 1854-1860. Stownik języka polskiego t. 1-6. Wyd. 2. Lwów: Zakład Ossolińskich.

Mackevì̌ Ûzefa F. Réd. 1982. Sloǔnik belaruskih gavorak paǔnočna-zahodnâj Belarusì iâe pagraničča t. 3, Mìnsk:,Navuka ì tèhnìka”, 249. [Мацкевіч Юзефа Ф. Рэд. 1982. Слоўнік беларускіх гаворак паўночна-заходняй Беларусі $i$ яе пагранічча t. 3, Мінск: „Навука і тэхніка”, 249].

Mayenowa Maria Renata, Pepłowski Franciszek. Red. 1966-2012. Słownik polszczyzny XVI wieku t. 1-34. K. Mrowcewicz, P. Potoniec. Red. t. 35-37. Wrocław: Ossolineum. 1966-1994. Warszawa: IBL PAN 1995-2012. 
Narodowy Korpus Języka Polskiego. Online: http://www.nkjp.uni.lodz.pl [Dostęp 17.02.2020].

Nowak Józef Karol. 2012. Słownik gwary górali żywieckich. Żywiec-Grójec-Warszawa: Wydawnictwo Żywia.

Oniškevič Mihajlo. 1984. Slovnik bojkivs'kih govirok. Kiïv: „Naukova Dumka”. [Онишкевич Михайло. 1984. Словник бойківських говірок. Київ: „Наукова Думка”].

Pìpaš Ûìj, Galas Boris. 2005. Materìali do slovnika gucul's'kih govirok. Kosìvs'ka Polâna i Rosiška Rahìvs'kogo rajonu Zakarpats'koïoblastì, Užgorod: Užgorods'kij nacìonal'nij unìversitet. [Піпаш Юрій, Галас Борис. 2005. Матеріали до словника гуиульських говірок. Косівська Поляна і Росішка Рахівського району Закарпатської області, Ужгород: Ужгородський національний університет].

Pstyga Alicja. 2010. Stowotwórcza kategoria negacji. Prefiksalne negatywa rzeczownikowe we wspótczesnym języku polskim i rosyjskim. Gdańsk: Wydawnictwo Uniwersytetu Gdańskiego.

Satoła-Staśkowiak Joanna, Koseska-Toszewa Violetta, przy współpr. Ludmiły Dimitrovej. 2014. Współczesny słownik bułgarsko-polski z. 1. Warszawa: Slawistyczny Ośrodek Wydawniczy.

Siatkowski Janusz. 1991. Stownik czesko-polski. Warszawa: Wiedza Powszechna.

Steffen Wiktor. 1984. Słownik warmiński. Wrocław-Warszawa-Kraków-Gdańsk: Zakład Narodowy im. Ossolińskich. Wydawnictwo PAN.

Sychta Bernard. 1967-1976. Stownik gwar kaszubskich na tle kultury ludowej t. 1-7. Wrocław: Zakład Narodowy im. Ossolińskich - Wydawnictwo PAN.

Šmelev Dmitrij. Red. 1986. Slovar' russkogo âzyka XI-XVII vv. Vyp.11. Moskva: „Nauka”. [Шмелев Дмитрий. Ред. 1986. Словарь русского языка XI-XVII вв. Вып. 11. Москва: „Наука”].

Szymczak Mieczysław. 1962-1973. Słownik gwary Domaniewka w powiecie łęczyckim t. 1-8. Wrocław-Warszawa-Kraków: Zakład Narodowy im. Ossolińskich - Wydawnictwo PAN.

Talanov Oleg. 2016. Pol's'ko-ukraïns'kij ukrä̈ns'ko- pol's'kij slovnik. Kiïv: Vidavnictvo „Arìj”. [Таланов Олег. 2016. Польсько-украӥнський українсько-польський словник. Київ: Видавництво „Арій”].

Urbańczyk Stanisław. Red. 1953-2002. Słownik staropolski t. 1-11. Kraków: Instytut Języka Polskiego PAN.

Jan Wawrzyńczyk. Red. 2009. Wielki stownik polsko-rosyjski. Warszawa: Wydawnictwo Naukowe PWN.

Zdanowicz Aleksander i in. Red. 1861. Stownik języka polskiego t. 1-2. Wilno. Online: http://eswil.ijp-pan.krakow.pl [Dostęp 24.02.2020].

Zgółkowa Halina. Red. 1995-2005. Praktyczny słownik współczesnej polszczyzny t. 1-50. Poznań: Wydawnictwo „Kurpisz”.

\section{ABOUT THE LEXEMES NIEWSTYD, NIEWSTYDNIK AND NIEWSTYDLIWIEC IN POLISH AND OTHER SLAVIC LANGUAGES}

Summary. On the basis of Polish and other Slavic historical and dialect sources, the author discusses the genesis and extent of the lexemes, niewstyd, niewstydnik, niewstydnica and niewstydliwiec in the common meaning of 'a man without shame, despicable'. These are archaisms that functioned relatively briefly in standard Polish (17th-18th centuries). They were displaced by the derivatives, bezwstydnik i bezwstydnica which had been spreading 
since the mid-17th century. The current occurrence of similar formations with the prefix nie- in the Czech language, and their historical presence in all East Slavic languages prove that these forms were previously functioning in extensive parts of the Slavic lands. In the Polish language area, they have only survived in regional dialects. Their presence, relatively limited in central and northern Poland, is mainly in the south (Silesia, Lesser Poland) and south-east.

Key words: history of the Polish language, dialectology, vocabulary, word formation

\title{
ПРО ЛЕКСЕМИ NIEWSTYD, NIEWSTYDNIK I NIEWSTYDLIWIEC У ПОЛЬСЬКІЙ ТА ІНШИХ СЛОВ'ЯНСЬКИХ МОВАХ
}

\begin{abstract}
Анотація. На матеріалі польських та іншослов'янських історичних і діалектних джерел Автор описує генезу й ареал поширення лексем niewstyd, niewstydnik, niewstydnica i niewstydliwiec, що мають спільне значення 'людина, позбавлена сорому, нікчемна'. Це архаїзми, які відносно недовго входили до складу загальновживаної лексики польської мови (XVII-XVIII ст.). Вони були витіснені дериватами bezwstydnik i bezwstydnica; згадані лексеми поширювались з середини XVII ст. Зараз існування форм із префіксом піе- в сучасній чеській мові, а також їх наявність у всіх східнослов'янських мовах у різні історичні періоди доводять, що в минулому ці форми функціонували на значній частині слов'янських земель. На польському мовному ареалі вони проіснували довше лише у діалектах. Аналізовані лексеми, відносно нечисленні на території центральної та північної Польщі, поширені, зокрема, на півдні (Сілезія, Малопольща) та південному сході.
\end{abstract}

Ключові слова: історія польської мови, діалектологія, лексика, словотвір 
